
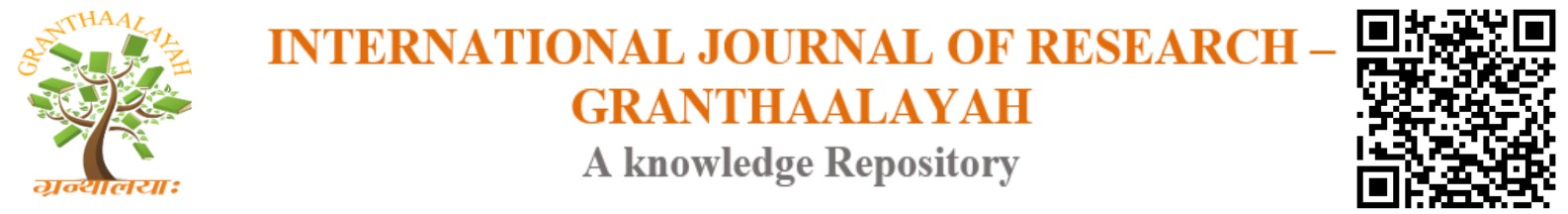

Science

\title{
KNOWLEDGE AND PERCEPTION OF CAUSES OF GROSS HAEMATURIA AMONG THE INHABITANTS OF KWALKWALAWA RIVERINE SETTLEMENT OF SOKOTO
}

\author{
Isah B A ${ }^{* 1}$, Musa Giro A ${ }^{2}$, Yahaya ${ }^{1}{ }^{1}$, Awosan KJ ${ }^{1}$, Ibrahim MTO ${ }^{3}$, Raji M.O ${ }^{1}$ \\ ${ }^{1}$ Department of Community Health, Usmanu Danfodiyo University, Sokoto \\ ${ }^{2}$ College of Health Sciences, Usmanu Danfodiyo University, Sokoto \\ ${ }^{3}$ Vice Chancelor, Alhikma University, Ilorin
}

\begin{abstract}
Blood in the urine is a common condition seen in people living around the riverine area which may result from bleeding anywhere along the urinary tract. Schistosomiasis is considered to be the commonest cause of haematuria among the inhabitants of riverine areas.

Urinary schistosomiasis affects more than 200 million people worldwide and poses a threat to 600 million in more than 76 countries (WHO, 1993). In Africa alone, about 192 million cases of schistosomiasis have been reported; with Nigeria ranking the highest (15\% of cases) followed by the United Republic of Tanzania (about 10\% of the cases) and the Democratic Republic of Congo and Ghana with 7-8\% each.

A descriptive cross sectional survey was conducted among the inhabitants of Kwalkwalawa village in Wamakko local government Sokoto state, Nigeria.

Majority of the respondents $(81.4 \%)$ had passed bloody urine at one time of their life-time, unfortunately only $3.1 \%$ of the affected respondents had ever being to Hospital for treatment. Only $5.7 \%$ relates hematuria to contact with river water and the Knowledge score of gross hematuria revealed that only $11.4 \%$ have good knowledge of the disease. Perceived Social determinants of the disease in the environment include; Farming, Fishing, washing and Bathing in the River as well as fetching for Domestic use. The lack of proper knowledge of the cause of the disease and insufficient safe water supplies coupled with inadequate health care facilities may have influenced the infection rate and distribution of the disease in the area. In conclusion the study was able to find out a high prevalence of hematuria among the inhabitants of this study area, however, there is poor knowledge of the cause of bloody urine. Most of the respondents believed that bloody urine can be cured and prevented, but few relate it to drug treatment.
\end{abstract}

Keywords: Knowledge; Perception; Gross Hematuria; Riverine Area.

Cite This Article: Isah B A, Musa Giro A, Yahaya M, Awosan KJ, Ibrahim MTO, and Raji M.O. (2017). "KNOWLEDGE AND PERCEPTION OF CAUSES OF GROSS HAEMATURIA AMONG THE INHABITANTS OF KWALKWALAWA RIVERINE SETTLEMENT OF SOKOTO." International Journal of Research - Granthaalayah, 5(8), 1-10. https:// doi.org/10.29121/granthaalayah.v5.i8.2017.2176. 


\section{Introduction}

Haematuria refers to appearance of red blood cells (RBCs) in the urine, which may either be visible to the naked eye (Gross or macroscopic hematuria) or detected with a microscope (microscopic hematuria). Blood in the urine is a common condition seen in people living around the riverine area which may result from bleeding anywhere along the urinary tract. One cannot readily distinguish between blood originating from the kidneys, ureters, bladder or urethra. However, schistosomiasis is considered to be the commonest cause of hematuria among the inhabitants of riverine areas.

Urinary schistosomiasis (Bilhaziasis) is a waterborne disease caused by a parasitic worm called Schistosoma haematobium, the disease is especially common among children in developing countries as they are more likely to play in infected water, this is the reason why studies on the epidemiology of urinary schistosomiasis in Nigeria and other countries mostly targeted the school children, while only a limited number of studies have been conducted at the community levels (Edingbola, L.D. 1988). Other high risk groups include farmers, fishermen and people using infected water for their daily chores.

The parasite is found in the venous plexus draining the urinary bladder. Durng infection, the parasites deposit terminal spine eggs which clog the venous plexus, impending blood flow. This bursts the veins, allowing blood and eggs to enter the urinary bladder resulting in the characteristics symptom of hematuria (WHO, 1985).

\subsection{Statement of the Problem}

Urinary schistosomiasis affects more than 200 million people worldwide and poses a threat to 600 million in more than 76 countries (WHO, 1993). In Africa alone, about 192 million cases of schistosomiasis have been reported; with Nigeria ranking the highest (15\% of cases) followed by the United Republic of Tanzania (about 10\% of the cases) and the Democratic Republic of Congo and Ghana with 7-8\% each (Hotez, et at., 2009).

About 200,000 deaths per annum occur as a result of schistsomiasis mainly through bladder cancer and rural failure. Individuals' perceptions on the causes and impact of urinary schistsomiasis differed by their levels of education and gender. There is little information on the epidemiology of schistosoma haematobium infection in Northern Nigeria, and the prevalence and distribution of the disease remain unknown in most of the areas in this geographical zone.

Schistosomiasis is regarded as a disease of poverty because it persists in rural marginalized areas of Sub-Saharan Africa whose people are often subsistence farmers with no education (Watts, 2008). Regardless of the burden it causes, the disease often receives little attention by healthcare providers, national governments and international agencies comprised to malaria, HIV/AIDS and TB, childhood diseases and diarrhea, simply because not every individual infected becomes immediately ill (Michaud, et al., 2003). 


\subsection{Rational of the Study}

Several factors, such as cultural, social, environmental and behavioral, directly influence the prevalence and intensity of schistsomiasis. It is important that these factors be identified to aid designing control program. In several areas in Nigeria, there is complete lack of knowledge on the factors associated with schistsomiasis transmission. Environmental conditions and sewage disposal are deplorable, indiscriminate defaecation and urination is very common, the literacy level is low and safe/portable water is greatly inadequate with consequent effects on the community health. Health education and promotion campaigns are essential for any change in behavior to be made. For health education and promotion activities to be effective, target audiences must be identified so that a clear message can be delivered, and hence local knowledge and perceptions must be taken into account (WHO, 1995). But, health education interventions have failed in the past. Some researchers conclude that promoting behavioural changes obscures underlying structural and political problem associated with diseases and is tantamount to victim blaming, while research from the last decade have shown that health promotion interventions failed because they were designed without knowledge of the health behavior of the target population (Godin and Sheppard, 1983). The study aims to assess the knowledge and perception on the causes of hematuria among the respondents as well as design a health education package program for the State Ministry of Health.

\section{Methodology}

\subsection{Description of the Study Area}

Kwalkwalawa is a Village under Wamakko Local Government of Sokoto State; the village is $8 \mathrm{~km}$ away from Sokoto Town. The state lies between latitude $13^{0} 04^{1} \mathrm{~N}$ and longitude $5^{0} 14^{1} \mathrm{E}$ with total land area of $25,973 \mathrm{~km}^{2}$ [SSGOD, 2003]. River Rima and River Sokoto pass through the kwalkwalawa fadama, the two rivers serve as the source of water for irrigation, fishing and other domestic needs. The village is located within the fence of the Usmanu Danfodiyo University Sokoto

\section{Materials and Method}

The study design was a descriptive cross sectional survey conducted among the inhabitants of Kwalkwalawa town in Wamakko local government Sokoto state, Nigeria aged 10 years and above. Random simple sampling technique was used to collect data from the respondents and the instrument used for data collection was an interviewer administered questionnaire consisting of both open and closed ended questions. The items of information was divided into 4 sections (A, B, C, \& D) involving Socio-demographic data of respondents, their Knowledge, perception and determinants of gross hematuria. Data was collected through the support of research assistants who were trained on how to administer the questionnaire and was analyzed using statistical package for social science (SPSS) version 20 computer software packages to produce frequency distributions of all variables. Descriptive statistics were used for qualitative and quantitative variables. The Chi-square test was used to compare differences between proportions. All statistical analysis was set at $5 \%$ level of significant, $\mathrm{p} \leq 0.05$ (i.e $95 \%$ confidence level) and a total of 286 study subject were enrolled in the study. Permission was obtained from the 
department of community medicine Usmanu Danfodiyo University Sokoto and an ethical approval from the Teaching hospital was obtained. An introductory letter with ethical approval was taken to the Village leader (Hakimi) and a verbal consent was obtained from the study subjects after explaining the objectives of the study to them prior to questionnaire administration.

\section{Results}

Two hundred and eighty six questionnaires were administered and only 280 were completed correctly and the information obtained was analyzed as follows;

Table 1: Socio-Demographic Characteristics of the Respondents; $\mathrm{N}=280$

\begin{tabular}{ll}
\hline Age & Frequency \\
\hline $10-19$ & $91(32.5 \%)$ \\
$20-29$ & $104(37.1 \%)$ \\
$30-39$ & $62(22.1 \%)$ \\
$40-49$ & $21(7.5 \%)$ \\
$50-59$ & $2(0.7 \%)$ \\
\hline Sex & \\
\hline Male & $271(96.8 \%)$ \\
Female & $9(3.2 \%)$ \\
\hline Religion & \\
\hline Islam & $280(100 \%)$ \\
Christianity & 0 \\
\hline Occupation of respondent & \\
\hline Student & $58(20.7 \%)$ \\
Civil servant & $8(2.9 \%)$ \\
Trader & $39(13.9 \%)$ \\
Farmer & $143(51.1 \%)$ \\
Fishing & $32(11.4 \%)$ \\
\hline Highest level of education & \\
\hline Qur'an & $196(70 \%)$ \\
Primary & $21(7.5 \%)$ \\
Secondary & $48(17.1 \%)$ \\
Tertiary & $15(5.4 \%)$ \\
None & 0 \\
\hline Marital status & \\
\hline Single & $160(57.1 \%)$ \\
Married & $119(42.5 \%)$ \\
Divorced & $1(0.4 \%)$ \\
Separated & 0 \\
Widow/widower & 0 \\
\hline
\end{tabular}

Majority of the respondents fall between the Age range of 10 to 29years $(69.6 \%)$ and $96.8 \%$ were all males; all the respondents were Muslims (100\%) and mostly farmers $(51.1 \%)$; single (57.1\%) and about 70\% had only Qur'anic education. 
Table 2: Prevalence of Gross Hematuria among the Respondents; $n=280$

\begin{tabular}{ll}
\hline Did you ever passed bloody urine? & Frequency \\
\hline Yes & $228(81.4 \%)$ \\
No & $49(17.5 \%)$ \\
Don't know & $3(1.1 \%)$ \\
\hline Are you still passing the bloody urine? & \\
\hline Yes & $106(46.5 \%)$ \\
No & $122(53.5 \%)$ \\
& $(\mathbf{n = 2 2 8 )}$ \\
\hline Were you ever being to hospital for & \\
treatment? & $7(3.1 \%)$ \\
\hline Yes & $221(96.9 \%)$ \\
No & $(\mathbf{n = 2 2 8 )}$ \\
\hline
\end{tabular}

Majority of the respondents $(81.4 \%)$ had passed bloody urine at one time of their life out of which $46.5 \%$ are still passing the bloody urine, unfortunately only $3.1 \%$ of the affected respondents had ever being to Hospital for treatment.

Table 3: Knowledge of Gross Hematuria among the Respondents; $n=280$

\begin{tabular}{ll}
\hline Aware of bloody urine & Frequency \\
\hline Yes & $275(98.2 \%)$ \\
No & $5(1.8 \%)$ \\
\hline Correct knowledge of the cause & $16(5.7 \%)$ \\
\hline Yes & $264(94.3 \%)$ \\
No & \\
\hline Can bloody urine be cured? & $201(71.8 \%)$ \\
\hline Yes & $79(28.2 \%)$ \\
No & \\
\hline Knowledge of treatment & $145(72.1 \%)$ \\
\hline Herbal concussion & $42(20.9 \%)$ \\
Drugs & 0 \\
Surgery & 0 \\
Prayer & $14(7 \%)$ \\
I don't know & \\
\hline Knowledge of complication & $216(77.1 \%)$ \\
\hline Yes & $64(22.9 \%)$ \\
No & \\
\hline What are the problems? & $93(42.7 \%)$ \\
\hline Infertility & $40(18.3 \%)$ \\
Bladder cancer & $31(14.2 \%)$ \\
Urinary tract obstruction & $19(8.7 \%)$ \\
Kidney failure & $49(22.5 \%)$ \\
I don't know &
\end{tabular}

\section{Is bloody urine inherited?}




\begin{tabular}{ll}
\hline Yes & $154(55 \%)$ \\
No & $126(45 \%)$ \\
\hline Is bloody urine related to river water? & \\
\hline Yes & $208(74.3 \%)$ \\
No & $72(25.7 \%)$ \\
\hline $\begin{array}{l}\text { Do you think the condition can be } \\
\text { prevented? }\end{array}$ \\
\hline Yes & $134(47.9 \%)$ \\
No & $146(52.1 \%)$ \\
\hline What method of prevention do you know? & \\
\hline Drugs & $38(28.1 \%)$ \\
Herbal concussion & $5(1.8 \%)$ \\
I don't know & $92(68.1 \%)$ \\
\hline
\end{tabular}

About $92.8 \%$ of the respondents knew that people around pass bloody urine however only $5.7 \%$ relates it to contact with water. Majority of the respondents $(71.8 \%)$ agreed that it can be cured however, only $20.9 \%$ relates it with drug treatment. The Knowledge score of gross hematuria revealed that only $11.4 \%$ have good knowledge

Table 4: Knowledge Score

\begin{tabular}{ll}
\hline Knowledge score & \\
\hline Good knowledge & $32(11.4 \%)$ \\
Poor knowledge & $248(88.6 \%)$ \\
\hline
\end{tabular}

Only $11 \%$ of the respondents have adequate knowledge of causes of gross haematuria

Table 5: Respondents' Perception on the Causes of Gross Hematuria; $n=280$

\begin{tabular}{ll}
\hline Is bloody urine normal? & Frequency \\
\hline Yes & $28(10 \%)$ \\
No & $221(78.9 \%)$ \\
I don't know & $31(11.1 \%)$ \\
\hline Is bloody urine related to puberty? & \\
\hline Yes & $58(20.7 \%)$ \\
No & $222(79.3 \%)$ \\
\hline Is bloody urine related to Food we eat? & \\
\hline Yes & $158(56.4 \%)$ \\
No & $122(43.6 \%)$ \\
\hline Is bloody urine related to evil spirit & \\
\hline Yes & $18(6.4 \%)$ \\
No & $262(93.6 \%)$ \\
\hline
\end{tabular}

Majority of the respondents (78.9\%) thought of bloody urine to be abnormal, $20.7 \%$ relates it to puberty, $56.4 \%$ to Food we eat, and $6.4 \%$ to evil spirit. 
Table 6: Perceived Causes of the Disease; $n=280$

\begin{tabular}{ll}
\hline Drinking water from the river & Frequency \\
Yes & $280(100 \%)$ \\
No & 0 \\
\hline Farm around the river & $279(99.6 \%)$ \\
\hline Yes & $1(0.4 \%)$ \\
No & \\
\hline Fishing in the river & $279(99.6 \%)$ \\
\hline Yes & $1(0.4 \%)$ \\
No & \\
\hline Wash plates and pots in the river & $269(96.1 \%)$ \\
\hline Yes & $11(3.9 \%)$ \\
No & \\
\hline Bathing in the river & $279(99.6 \%)$ \\
\hline Yes & $1(0.4 \%)$ \\
No & \\
Do Animals drink and bath in the river? & $274(97.9 \%)$ \\
\hline Yes & $6(2.1 \%)$ \\
No & \\
\hline Urinate and/or defecate in the river & $260(92.9 \%)$ \\
\hline Yes & $20(7.1 \%)$ \\
No &
\end{tabular}

The table above identifies some perceived determinants of the disease in the community; Drink water from the river (100\%), Farm around the river (99.6\%), Fishing in the river (99.6\%), Wash clothes, plates and pots in the river (96.1\%), Bath in the river (99.6\%), Animals drink and bath in the river $(97.9 \%)$, Urinate and/or defecate in the river (92.9\%).

\section{Discussion}

This study identified the prevalence, knowledge, perception and determinants of the causes of gross hematuria among the inhabitants of Kwalkwalawa riverine area of Sokoto. Two hundred and eighty questionnaires were administered, correctly filled and analyzed using statistical package for social science (SPSS) version 20 computer software packages.

Majority of the respondents (69.6\%) were aged $10-29$, Males by gender (96.8), Muslims $(100 \%)$, Farmers $(51.1 \%)$, Single $(57.1 \%)$ and about $70 \%$ attend only Qur'anic school.

Two hundred and twenty eight respondents (81.4\%) replied that they had passed bloody urine at one time of their life which is higher than that of Kenya where the prevalence ranges from 5\% to 65\% [Karajan DM, et al, 1998; Mwinzi PN, et al, 2004; Oman JH, et al, 2001]. The lack of proper knowledge of the cause of the disease and insufficient safe water supplies coupled with inadequate health care facilities may have influenced the infection rate and distribution of the disease in the area. 
The knowledge score of gross hematuria revealed that only $11.4 \%$ of the respondents have good knowledge and only $5.7 \%$ attributed it to contact with river water, which is slightly lower than a study conducted in Kano state, Nigeria where $25.8 \%$ of respondents have attributed urinary schistosomiasis to contact with water bodies [Sarkinfada et al, 2009] and this might be due to the fact that both States lies in the same Geopolitical region of North-west where level of awareness is still ranked low. This is contrary to a research conducted in Volta Basin of Ghana where 88.7 99.4\% acknowledged Schistosomiasis as a disease associated with the Volta Lake/River [Dzidzo Regina Y. et. al, 2011]. Also in a research to determine some behavioral practices that predispose vesicular Schistosomiasis transmission in endemic communities of Niger Delta, $76.04 \%$ of the respondents showed good knowledge of the disease; more males than females affected $(79.34 \%)$ and $(72.42 \%)$ respectively. About $76 \%$ of the respondents were knowledgeable about the disease syndrome, probably due to their high level of awareness [Onyirioha, 2010].

Perception score revealed that; about $63.6 \%$ of the respondents have good perception of the disease, only $36.4 \%$ relates it to inheritance, puberty, food we eat, and evil spirit. This is contrary to a study done in Northern Cameroon on some social determinants of Urinary Schistosomiasis which reports that 'Exposure to sun was the reported cause of hematuria [53\% adult and 62\% children respondents], followed by drinking of dirty water [ $18 \%$ adults and $41 \%$ children]. Only $15 \%$ of adult and $26 \%$ school children could relate hematuria to wading, a common means of exposure to urinary schistosomiasis [Jean M. et. al, 2004].

Majority of the respondents perceived the social determinants to hematuria in the environment as Farming (99.6\%), Fishing (99.6\%), Drinking (100\%), washing, bathing, urinating and defecating around the river. This is similar to a research to determine some behavioral practices that predispose vesicular Schistosomiasis transmission in endemic communities of Niger Delta, where most respondents $74.85 \%$ said that they defecated into the surroundings and used the pond/stream water for domestic purposes. Only $25.15 \%$ showed good habits and practices that would assist in the control of the disease transmission. The respondents claimed to defecate into pit Latrine usually; not making regular use of pond/stream water and only use rain water when and where available [Onyirioha, 2010].

\section{Conclusion}

The study was able to find out a high prevalence $(81.4 \%)$ of hematuria among the inhabitants of the study area; however there is poor knowledge of the cause of bloody urine whereby only $11.4 \%$ shows good knowledge. Perceived Social determinants of the disease in the environment include; Farming, Fishing, washing and Bathing in the River as well as fetching for Domestic use. The lack of proper knowledge of the cause of the disease and insufficient safe water supplies coupled with inadequate health care facilities may have influenced the infection rate and distribution of the disease in the area.

\section{Recommendations}

1) Pipe borne water should be provided in order to reduce their dependence on open water bodies for drinking and other domestic uses. 
2) Health education is necessary to raise awareness on the social factors that predisposes to development of Schistosomiasis and early treatment of its related symptoms like hematuria.

\section{References}

[1] Dzidzo Regina Yirenya-Tawiah, Ted Annang, Joseph Otchere, Daniel Bentum, et al (2011); Urinary Schistosomiasis among Adults in the Volta Basin of Ghana, Prevalence, Knowledge and Practices. J Trop Med Parasitol.; 34:1-16.

[2] Ejezie, G.C, and Ade-Serrano, M.A. (1981) Schistosoma Haematobuim in Ajara Community of Badagry, Nigeria; A Study of Prevalence, Intensity and Morbidity from Infection among Primary School Children. Tropical and Geographical Medicine 33, 175-180.

[3] Ekanem, E.E et al (1994). Effects of Schistosoma Haematobuim on the Physical Growth and School Performance of Nigerian Children. Central African Journal of Medicine, 40, 32-44.

[4] Faruk Sarkinfada, Azeez-Akande Oyebanji, Isa Abubakar Sadiq, Zubairu Ilyasu; Urinary schistosomiasis in the Danjarima community in Kano. J Infect Dev Ctries 2009; 3(6):452-457.

[5] Froog NeIson, Samoan/ S.A, MaIIah, M.B and AIIam A.A, (1966) the Epidemiology of Schistosoma Haematobium and Schistosoma Mansoni Infections in the Egypt 40 Project Area 2. Prevalence of Bilharzias is in Relation to Personal Attribute and Habits. Bulletin of WHO 23, 293- 318

[6] Imatidoa, E.U (1991) Ecological Studies of Fresh Water Snail Ibadan Nigerian Journal of Parasctology 12, 59-63

[7] J.N.N ONYIRIOHA (2010): Impact Assessment of Vesicular Schistosomiasis on Educational Performance of Primary School Pupils on Niger Delta. Inter-world journal of science and technology vol. 4 No. 1: 23-26.

[8] J.N.N ONYIRIOHA (2010): Perception, Attitude and Some Behavioural Practices That Predispose Vesicular Schistomiasis Transmission in Endemic Communities of Niger Delta. Interworld journal of science and technology vol. 4 No. 1: 27-31.

[9] Jean Meli, Simeon Fotso, Fru Angwofo III, Raoul Kamajeu, and Peter M. Ndumbe (JulyDecember 2004). African Journal of health sciences, volume 11, number 3-4,

[10] KIoos, H, Higashi, G.I Cattani, I.A; Shiluoka, U.D. Mansour, N.S. AndmurreI, K.D (1983) Water Contact Behaviour and Schistosomiasis in Upper Egyptian Village Social Science and Medicine 17, 545-562.

[11] Kiran Singh and D. Mudassiru(2014); Epidemiology of Schistosomiasis in school aged children in some riverine areas of Sokoto, Nigeria. Journal of Public Health and epidemiology 197-201.

[12] MOPHS. (2011) National multi-year strategic plan for control of Neglected Tropical Diseases 2011-2015.

[13] Mwinzi PN, Karanja DM, Kareko I, Magak PW, Orago AS, et al. (2004) Short report: Evaluation of hepatic fibrosis in persons co-infected with Schistosoma mansoni and human immunodeficiency virus 1. Am J Trop Med Hyg 71: 783-786?

[14] Okwosa, V.N (1982) Studies on Ecology and Distribution of Schistosoma Vectors and other Snail Jauna in South Western Nigeria. Nigeria Journal of Parasctology 3, 149-168.

[15] Oman JH, Vennervald BJ, Butterworth AE (2001) Morbidity in schistosomiasis: an update. Trends Parasitol 17: 117-118.

[16] Onyirioha, J.N.N and Arene O. (1994) Progressive Assessment of Prevalence of Urinary Schistosomiasis in Hyper-endemic Communities of Niger Delta Area of Nigeria. Nigeria Society for Parasitology 18th Annual Conference, Awka, Paper 18.

[17] SSGOD. 2003. Sokoto State government official diary, 2003 A'lumma printing press Ltd. Sokoto. Pg 12-17. 
[18] Steinmann P, Keiser J, Bos R, Tanner M, Utzinger J (2006) Schistosomiasis and water resources development: systematic review, meta-analysis, and estimates of people at risk. Lancet Infect Dis 6: 411-425.

[19] Tiglao, TV, (1982) Health Knowledge Attitude and Practices Related to Schistosomiasis in Layette. Tropical Medicine, 24, 10-114

[20] Ukoli, F.M.E and Asumu D.I (1979) Fresh Water Snails of the Proposed Federal Capital Territory in Nigeria. Nigeria Journal of Natural Science S. 1, 47-56

[21] UKWANDU, N.C.D. \& NMORSI, O.P.G. (2004) - The perception, beliefs and practices toward genitourinary schistosomiasis by inhabitants of selected endemic areas (Edo/Delta States) in southeastern Nigeria. Rev. Inst. Med. trop. S. Paulo, 46(4):209-216.

[22] WHO (2010). Preventive chemotherapy data bank. World Health Organization, Geneva.

[23] World Health Organization (1993), the control of schistosomiasis. WHO Technical Reports Series. 830.

[24] World Health Organization (WHO) Geneva (1957), Study Group on the Ecology of Intermediate Snail Host of Billarzasis report. WHO Technical Reports No 120.

*Corresponding author.

E-mail address: drbalaargungu@ gmail.com 